\title{
Finance Capitalism, Landnahme and Discriminating Precariousness - Relevance for a New Social Critique
}

\author{
Klaus Dörre ${ }^{*}$ \\ ${ }^{1}$ Friedrich-Schiller-Universität Jena, Institut für Soziologie, Carl-Zeiß-Straße 2, 07743 Jena, Germany
}

KEYWORDS

Capitalist Landnahme

Critique of capitalism

Discriminating

precariousness

Dynamics of capitalism

Exploitation

Financial market

capitalism

Social classes
A BSTRACT

This contribution discusses the return of the 'social question' to the basically still wealthy and secure societies of the Global North. Referring to the case of German welfare capitalism, a historically new form of discriminating precariousness is being identified. This type of precariousness results from processes of a market driven, capitalist Landnahme. The paper argues that this specific form of precariousness should be the subject matter of a renewed, scientific social critique.

\section{Introduction}

For some time now, the wealthy countries of the world have been experiencing the return of social insecurity (Castel 2009). This trend has only been exacerbated by the global financial and economic crisis. Social scientists, as well as politicians, seem to find it difficult to pinpoint exactly what is new about these developments and to offer comprehensive analyses. The following presentation is an outline of a possible interpretation that construes the social question, as posed at the onset of the $21^{\text {st }}$ century in the capitalist heartlands, as the expression of a new cycle of 'Landnahmen'1.

\footnotetext{
* Contact address: klaus.doerre@uni-jena.de (K. Dörre)

${ }^{1}$ Landnahme is a German term, its original meaning is 'land grab', mostly used in the context of settlement in or conquering new territory. It is, of course, used figuratively, to describe the expansion of capitalistic social and economic structures at the cost of non-capitalistic ones. The concept of Landnahme argues that in the long run capitalist societies cannot reproduce themselves on their own foundations. In order to reproduce themselves, they continuously have to occupy and commodify a non-capitalist 'other' (i.e. regions, milieus, groups, activities).
} 
Fordist Landnahme after 1945 brought forth a form of capitalism with no visible industrial reserve army; the finance-driven Landnahme that began in the 1970s has to a certain extent reversed this development. The revitalization of the reserve army mechanism has given rise to a new form of precariousness that has irreversibly changed the face of (not only) the wagelabour societies of continental Europe. In the following, I shall back up this view in a series of stages. First, I will theorize the link between capitalist Landnahme and precariousness. This is followed by an outline of current precarization tendencies ( 2 and 3 ), which lead to some concluding thoughts on the relevance of a new social critique.

\section{Capitalism, Landnahme, and Precariousness}

My deliberations build on a theoretical concept developed as a result of a productive, critical examination of Hartmut Rosa's theory of social acceleration and Stephan Lessenich's theory of activation (Dörre, Lessenich and Rosa 2009). The following arguments concentrate on the theory of Landnahme. First, however, I will present some basic theoretical ideas on capitalism and its radical dynamism.

\subsection{The Dynamism of Capitalism}

Capitalism cannot be reduced to a social subsystem such as economics. Rather it is a social formation, in which the economic system imposes a specific social order or fundamental rule on society (Streeck 2009: 232). This fundamental rule can be generalized and understood as the formula moneycommodity-(more) money (M-C-M'). Capitalism can be basically described as an 'absurd system' (Boltanski and Chiapello 2003: 42), in which the mass of producers lost the property rights to the products of their labour, while a relatively small group of capitalists remains chained to a process that is completely divorced from real consumption needs and use value, and aims only to the self-expansion of value - the increase of capital for its own sake. This division into use value and exchange value contains the possibility of crises. Nevertheless, it has been repeatedly possible to motivate not only 
capitalists, but also the masses to participate in this 'absurd system'. Apparently, a special 'spirit of capitalism'2 ascribes meaning to wage labour and other activities that keep the system functioning. The 'spirit of capitalism' is an ideological system, but it is not false consciousness. Rather individuals or social groups adopt motivations, techniques, and modes of thinking they need in order to be capable actors, within a capitalist system. This synchronization between social actors' motives and systemic requirements is facilitated by mediating institutional systems and modes of regulation, which suggest certain strategies to capitalist actors, and make others less likely.

This basic definition of a capitalist society is not original. However, it differs from others as it accentuates the ways in which capitalism processes and highlights the logic of dynamization inscribed in its development. Capitalism is first and foremost a structured process that can be analysed on the socio-economic level as Landnahme, on the cultural level as acceleration, and on the political level as activation. However, these principles are interlinked and mutually reinforcing. Capitalism cannot develop without continuously and with increasing speed, occupying 'new land' and activating social actors. As the promise to meet the growing demands of welfare can no longer be adequately fulfilled, the logic of dynamization has apparently surpassed a critical boundary. The discrepancy between meeting society's needs and continued growth has resulted in a fragile 'stabilization of the instable'. A capitalist society can only be reliably stabilized when the basic principles of dynamization can be applied successfully: when new land is continually appropriated, when acceleration increases, and activation becomes more comprehensive. But this logic of continuous augmentation is now not only approaching its human and natural limits, it also undermines the very foundation that makes 'societal market' (Marktvergesellschaftung) possible.

This last idea is constitutive for the concept of Landnahme. At its core the theory provides an actor-oriented understanding of capitalism as outlined by Pierre Bourdieu in his early study of the transitional Algerian

\footnotetext{
${ }^{2}$ The spirit of capitalism is precisely the set of beliefs associated with the capitalist order that helps to justify this order and, by legitimating them, to sustain the forms of action and predispositions compatible with it.' (Boltanski and Chiapello 2007: 10).
} 
society (Bourdieu 2000). Bourdieu clearly shows that a rational, calculating, way of thinking is not an ahistorical and natural trait of the homo economicus; rather, it is the product of specific historical conditions. Rational, calculating behaviour depends on the individual's ability to 'appropriate' his or her own future and, as Bourdieu has shown, this consciousness of the future as a space of opportunities and choice presupposes a minimum of income and job security. Even Schumpeter's entrepreneur, confronted with structural insecurity, needs a minimum level of security for his or her creative destruction. In an entrepreneur's own quintessential (profit) interest, he or she aims at temporarily limiting the arbitrariness of market competition. To this end, the entrepreneur uses the power resources at his or her disposal. Market-socialization is thus founded on contradictory, even opposing, logics of practice. Every act of exchange regulated by prices, if it is not looked upon in isolation, is socially embedded in a time regime that transcends the restricted horizons of market-driven acts of exchange. In particular, societies of advanced capitalism, with their differentiated subsystems, have to meet this requirement. Nevertheless, capitalist actors, in their search for 'new land', are continually developing new strategies in order to resolve the tension between market competition and fundamental securities in favour of the former. It is exactly this tension that is reflected in the concept of Landnahme.

\subsection{Capitalist Landnahme and Precariousness}

Marx himself provided a first examination of capitalist Landnahme. In his analysis of 'so-called primitive accumulation' (Marx 1977 [1867]: 741 ff.), he sketches the emergence of capitalism in a non-capitalist environment. Marx believed that capitalist property and class relations preceded the capitalist mode of production. The expropriation of the peasants is the precondition for the creation of '[f]ree labourers, in the double sense', emancipated from serfdom and the guild. Marx describes this as an extremely brutal process of the expropriation of peasant farmers, the forcible confiscation of church property, colonial suppression, and slave trading. In the end, the means of production are monopolized by a small group of proprietors. Although Marx polemically exaggerates the brutality of this transition (Thompson 
1966: 189ff.), his ideas are still useful for a heuristic of current Landnahme processes.

Landnahme means primarily (1) internal and external expansion of capitalist modes of production. In the end, however, only large industry was able to provide the necessary foundation for capitalist agriculture and finalize the separation of farming and rural home industry as well as to 'conquer [...] for industrial capital the entire home market' (Marx 1977 [1867]: $776 \mathrm{f}$.). If we take into consideration that capitalist production did not become widespread until the Industrial Revolution, we must assume that for an entire era, capitalist and non-capitalist modes of production, class relations, and life styles existed side by side. It is difficult to clearly delineate old and new relationships. They are synthesized in myriad ways in the daily lives of individuals and social groups. Seen in this way, the doubly emancipated wage labourer described by Marx is an abstraction. Even after the industrial revolution, large segments of the industrial proletariat remained bound to rural, traditional means of production and ways of life.

Neither changes in ownership and the expropriation of the peasants nor trimming and disciplining the freed labourers to fit the new mode of production could take place without state support. Processes of Landnahme are therefore (2) always also political processes. Legislation stemming from the feudal era was used to subjugate labourers and regulate wages. The mobilization and disciplining of the population for capitalist production was not only, and sometimes not even primarily, based on economic incentives, but was supported to a great extent by coercive government mechanisms. Marx was convinced that the extensive use of political force, including violence, would be limited to the early history of capitalism. He expected a labour force to emerge 'which by education, tradition, habit, looks upon the conditions of that mode of production as self-evident laws of nature'. Noneconomic violence would then be used only as an exception; as a rule, 'the labourer can be left to the "natural laws of production"' (Marx 1977 [1867]: 765).

However, if we analyse the development of capitalism as a series of varying combinations of modes of production, class relations, institutional structures, and systems of legitimation, we must doubt the general validity of this Marxist premise. The development of capitalism, as diverse theorists, 
such as Rosa Luxemburg and Hannah Arendt, have stressed, is (3) always two-dimensional. On one hand, the development takes place at the sites of production of surplus value: in factories, within capitalist agriculture, and on commodity markets. On this hand, the founding pillars of capitalism also reproduce capitalism. On the other hand, the development leads to an exchange between accumulation of capital, and on the other hand, noncapitalist modes of production and territories. Rosa Luxemburg theorized that 'internal markets' (2003) can only absorb a fraction of a society's total output. The limited capacities of internal markets to satisfy capital's thirst for accumulation forces need to expand to 'external' markets.

For this reason, Landnahme describes capitalist accumulation as a (4) continuous process of expanding boundaries to offset the structural limits of 'internal' markets, and the attempts by human and non-human nature to transcend them, at least for a time. Luxemburg succinctly analysed the problem of capitalist development: its structural need for continuous growth. The individual capitalist who fails to continually upgrade his or her means of production and increase output risks his or her own demise. Production on the whole tends to be one step ahead of solvent demand, and the mass of material products tends to be ahead of increases in value because of increases in productivity. The systematic pressure to expand reproduction therefore goes hand in hand with the complex problem of realization that cannot be contained in a simple theory of underconsumption; an allegation often made against Rosa Luxemburg's theory.

Accumulation of capital requires the creation of surplus value through production. In order for expanded reproduction to be successfully accomplished, the surplus value must take the form of money. If surplus value is realized successfully, the available money-capital takes on a new productive form: it must be transformed into labour power and the means of consumption, and investment necessary for expanded production. Finally, it is indispensible to bring the expanded volume of commodities to the market, meaning that they in turn are transformed into money. Expanded reproduction is only successful if this last step is fulfilled. Within this process of production and circulation, the individual capitalist is at the mercy of society, for he is unable to expand market demand by himself. As an individual, the capitalist is powerless to overcome the 'realization 
problem'. The outcome is a constant imperative of growth. The resulting tensions explain for Luxemburg the 'contradictory phenomena that the old capitalist countries provide ever larger markets for and become increasingly dependent upon one another, yet on the other hand, compete ever more ruthlessly for trade relations with non-capitalist countries' (Luxemburg 2003: 347). These developments, she concludes, are the reason for imperialist expansionism.

As inspiring as Luxemburg's analysis of capitalist processes of Landnahme is, its underlying theory of collapse appears problematic from today's point of view. Certainly some aspects of capitalist Landnahme are irreversible; for example when it absorbs traditional modes of production or consumes natural resources. The thorough capitalization of 'external markets' seems to be a process that must come to an end at some distant point; without an 'outside' there can be no capitalism. However, there is an alternative way of understanding the process through the theory of Landnahme. According to this perspective, capitalist actors are (5) able to overcome the limits of internal markets by means of 'passive revolutions'. The regime of accumulation and property relations, means of regulation and production are transformed by capitalist actors - without a master plan and often via massive social conflicts - and thus used to stabilize the capitalist regime (Gramsci 1991: 101 f., 1999: 2063 ff.). These transformations are possible because within a concrete spatiotemporal regime capitalism is always able to reference an 'outside', which it sometimes even helps create. 'Capitalism can either make use of some pre-existing outside (non-capitalist social formations or some sector within capitalism - such as education - that has not yet been proletarian), or it can actively manufacture it' (Harvey 2005b: 141).

Actively manufacturing an 'outside' implies (6) that the Landnahme chain is basically infinite, a premise that decouples the theory of Landnahme from collapse theory interpretations. The 'original sin' of 'superseding purely economic laws through political action' (Arendt 1968, 2006: 335) can and must continually repeat itself at each further step. The dynamics of capitalism are ultimately founded on the ability to both produce and destroy space in time. Through investments in machines, factories, labour, and infrastructure, capital makes spatial commitments that it cannot break 
without producing costs and friction. Of particular importance are investments that open up spaces for economic exploitation, e.g. infrastructure investments in transport routes and railways, the exploitation of resources or also investments in education, job safety, and public health. These investments can only yield returns over longer periods of time. They are taken out of the primary cycle of capital (direct consumption) and diverted into the secondary (capital for the means of production, creation of funds for consumption, e.g. housing) or tertiary cycle (i.e. expenditures for research, development, social services). In addition, there is no certainty that such investments will bring returns. For this reason, the state often takes on the role of the 'ideal collective capitalist' (ideeller Gesamtkapitalist), whenever such long-term investments must be made. In this way, outside emerges for the individual molecular capitalist operations, a sphere which private accumulation cannot penetrate, could be used to improve economic performance.

To the extent that such containment of market societalization becomes a hindrance to capital utilization, it provokes attempts to loosen or even remove the spatiotemporal fix of capital that preceded it. When the removal of these fixes - as a result of internationalization for example - leads to deindustrialization, economic collapse, mass unemployment, and poverty, a new outside emerges, comprised of ravaged regions and unutilized labour that, in a later developmental phase, can become the object of long-term investments.

This synchronicity of the asynchronous could (7) be used to conserve and institutionalize secondary exploitation. Secondary, in this case, by no way means less painful, less brutal, or less important. Rather, secondary exploitation implies that rationality of the exchange of equivalents no longer holds, or only within limitations. The functionalization of the reproductive women's labour or the installations of transitory legal statuses for migrants are classic examples for the way in which secondary exploitation works. In the first case, symbolic/normative and political/institutional mechanisms are used to create hierarchical, gender-specific labour constructions. This is the historical foundation of the devaluation of reproductive labour and women's relative exclusion from full-time employment that includes a social safety-net (Aulenbacher 2009: 65-80). In the second case, the transitory legal 
status of migrants - based on relative disenfranchisement and deracination stabilizes a specific inside/outside differentiation. This differentiation aims at securing cheap labour that could be mobilized for unattractive segments of labour market, offering jobs with low qualification, high strain, and low pay.

Thus we can always speak of secondary exploitation, when symbolic forms and political force are used to conserve the differences between inside and outside, to devalue the labour of certain social groups, or to exclude these groups from the main capitalistic exploitative relationship. Secondary, exploitation exposes a tension-filled synthesis of universalism and particularism inherent to every capitalist Landnahme. The universalist claim of the utilization of capital is functionally dependent upon particular regulatory systems, such as the nation-state. The global economic system can only exist within a network of national and international power relations, that continually (re)produce the demarcation of inside and outside.

With this in mind, we can define more precisely (8) the significance of the processes creating precariousness for the economic rationality of capitalism. The mechanism of the reserve army analysed by Marx in the first volume of Capital (Marx 1977 [1867]: 657 ff.) is to a certain extent a form of actively creating an outside that is in direct opposition to government decommodification. The industrial reserve army, in its myriad manifestations, could be utilized in boom phases to mobilize an additional workforce. Particularly in times of crisis, those normally excluded from capitalist production can be used to pressure established workers not to make demands, thereby keeping labour costs as low as possible (Harvey 2005b: 139). Marxist readings of the social question have thus always differentiated between an inside and an outside. Inside, the focus is on exploitation, on the private appropriation of collectively produced surplus value. Outside, the emphasis is on keeping salaries low and living standards below the usual class standards, on overexploitation, and, in the most extreme case, on excluding certain segments of the workforce from the labour market - and therewith from wage labour and the ability to make a living.

This inside/outside dialectic of capitalism unfolds in different eras and social spaces (9). The Algerian 'laboratory' analysed by Pierre Bourdieu (2000) was a repetition of 'primitive accumulation', at the temporal and 
spatial periphery of prospering capitalism, and is an example of a historically particular linkage of capitalist Landnahme and precariousness. Although the conclusions regarding the destructive effect of precarious living conditions are similar, Bourdieu's analysis diverges from Marx's in one important respect. For Marx, the main form of the industrial reserve army is a potential segment of the working class and differences can be overcome through 'regular cooperation between employed and unemployed' (Marx 2007 [1867]: 702), through political or trade union class unity. Marx even sees 'orphans and pauper children' as 'candidates for the industrial reserve army' who are 'in times of great prosperity [...] speedily and in large numbers enrolled in the active army of labourers' (Marx 2007 [1867]: 706). Only the lumpen proletariat, the vagabonds, and criminals, as well as those unable to work, the mutilated, the sickly, and the widows are seen by Marx as 'dead weight' that cannot be integrated into the working class (Marx 2007 [1867]: 707).

In contrast, for Bourdieu, the Algerian sub-proletariat represents an autonomous class, whose living conditions block any vision of class unity among the oppressed. These living conditions make it impossible for the sub-proletariat to acquire the planning, calculating way of thinking that allows for rational participation in the capitalist labour market. The subproletariat therefore habitually remains within a non-capitalist mode of production. For them, work is linked to honour and self-esteem. Often they work as street vendors, although they are unable to make a living from this work. These pre-modern practices are validated by a peasant moral of the past. It is better to work even without making a livelihood in order to maintain one's dignity. 'In fact, the activity has no other purpose than maintaining self-esteem' (Bourdieu 2000: 75).

Implicitly, Bourdieu's diagnosis is at odds with the optimistic belief in progress still harboured by some schools of Marxism. It makes no sense to categorize the Algerian sub-proletariat and its lifestyle as 'backwards'. The living conditions of the precariousness often allow them no other option than to hold onto a past, whose production conditions have increasingly disappeared in the process of societal evolution. As such, precariousness is in no way an expression of backwardness. Rather it is an odd synchronicity of the asynchronous. The precarious form is the other face of labour without 
which the 'anterior', modern expression of wage labour in the spatiotemporal configuration that we have analysed, could not have made its mark. This should be remembered in the perusal of the following analysis of current forms of precariousness.

\section{Finance-Capitalist Landnahme and Discriminating Precariousness}

The current form of discriminating precariousness is the result of the mode Landnahme is driven by finance capitalism that redefines a central feature of welfare capitalism. The reserve army mechanism, which temporarily disappeared in urban centres after 1945, or had at least become imperceptible, has now returned. A sector of precariousness is expanding and has become the functional equivalent of the traditional reserve army sector, whose absorption in the process of capitalist Landnahme has been most impressively described by the German sociologist Burkhart Lutz (1984).

\subsection{Neutralization of the 'Law of Wages' and Marginal Precariousness}

Lutz believes that the remarkable post-war prosperity in Germany was the result of historical conditions that cannot be reproduced at will. The weak growth of capitalism after the First World War was the result of capitalist actors' inability to overcome the dualism of the modern industrial sector and the traditional sector, limiting solvent demand within society. The exchange relations of modern industry and a sector structured by small businesses and agriculture with pre-modern lifestyles and value orientations kept labour costs low over a long period of time. This was in part due to the traditional sector that acted as a pool of potential labourers, which industry could utilize as needed, returning 'excess' labour to this outside area. Wages circulated around a margin that was to a great extent influenced by the consumption of goods in traditional sector. The costs of reproducing labour power remained limited as workers received a large percentage of the goods they needed to survive from the traditional sector - dominated by trades and agriculture - which offered more or less low-cost products. 
There were political conditions - the increased importance of government intervention as seen in the North American role model of the New Deal including mass production, mass consumption, and individualistic lifestyles, as well as consensus among elites that workers should partake in increased productivity - that played the key role in allowing capitalist actors in Western European urban centres to break the 'law of wages'. ${ }^{3}$ The neutralization of the 'law of wages' was part of a process, in which the traditional sector was absorbed irreversibly. As long as the traditional sector's functions for the reproduction of labour could not be delegated by the industrial and capitalist market, these functions had to be fulfilled by the state and the expanding public sector. As a result, real wages quadrupled during a twenty-year period (1950-1970), marking a unique quantitative and qualitative rise in employees' standard of living (Mooser 1984). More importantly, wage labour could be coupled with a strong social safety net and participatory rights. The generalization of wage labour, or the freeing of manpower for the capitalist labour market (commodification), was only possible because of an expanded welfare state that ensured wage labour to be decoupled from market risks (de-commodification). Despite continued inequalities and hierarchical structures, a 'society of the similar' emerged (Castel 2005: 46); it gives large numbers of wage earners access to the lifestyle and security standards of the middle classes. Central to this collective advancement was the availability of social property - to secure collective existence - manifested in entitlement to pensions and insurance payments in case of illness, as well as in the universal scope of collective bargaining agreements, and in an expansion of democratic participation in the workplace and society at large.

Characteristic for this short phase of 'capitalism with no reserve army' (Lutz 1984: 186) is the marginalization of precariousness and poverty. For women, migrants, and unqualified workers precariousness and poverty continued to be a bitter reality, primarily existing in areas outside of protected employment. Poverty became the problem of minorities in social proximity the 'socially despised' (Dahrendorf 1967: 88), the five or so per

\footnotetext{
3 The 'law of wages' as defined by Lutz (1984: 210) is that 'wages in the modern economy cannot rise significantly or permanently above the standard of supply - defined primarily through a barter economy - in the poorer segments of the traditional sector'. 136
} 
cent at the bottom of the social ladder. Although they did not match these groups one to one, the essential core of the poor was made up of those who seemed incapable of securing their own livelihood. In social proximity to these marginalized groups, precarious workers lived in their own world, together with those dependent upon social services. But for the majority within societies dominated by wage labour, pauperism seemed to be a thing of the past, at most a problem for welfare institutions.

\subsection{Finance - Capitalist Landnahme}

The marginalization of poverty and precariousness had its price. Predominantly stimulated by government intervention, Fordist Landnahme displaced the traditional sector's characteristic products and services and mobilized labourers from non-capitalist areas for industry and modern services. Strengthening one another, both processes caused a 'progressive destruction of the structures, modes of production, lifestyles, and behaviour orientation that had previously been constitutive for the traditional sector'. This inner Landnahme is, according to Lutz, analogous to the external Landnahme of imperialism (Lutz 1984: 213), achieved at the price of the spreading destruction of natural resources, aggravation of the North-South conflict, and growing tensions at the centres of developed capitalism. After the complete absorption of the traditional sector, social preconditions for the seemingly 'everlasting' prosperity disappeared. The dynamic of growth weakened and the resulting instabilities prepared the terrain for a new cycle of Landnahme that - when it focused on the centre of developed capitalism had its sights on the outside, created by the de-commodification policies of the Fordist era.

Finance-driven Landnahme is a dynamization of capitalist accumulation through occupation of an outside that was forced upon capitalism by institutions that regulated markets as well as by the incorporation of workers' participation. In this context, financial market capitalism is a distinct phase in capitalist development, founded on a specific modus operandi of Landnahme. In general, processes of Landnahme are not linear; they are always influenced by accidents and contingent decisions. They create tensions and contradictions, incite opposition, and are a motivation for 
protest and resistance. Nevertheless, this modus operandi of capitalist Landnahme comprises a dominant element reflected in long cycles of opening and closing of markets. To this day, this finance-driven mode rests on the relative dominance of - often fictitious - investment capital. The regime of Wall Street, and the American monetary policy created the maintenance of its leading role in the global economy - with the active help of European governments, which made sure that constitutive elements of financial capitalism were integrated in continental European economies. Because of the hierarchies in the system of international governments, this type of capitalism was able to expand. As a result, the principles of liquidity management inherent to global financial markets were successively transferred to the real economy.

Two groups of causes bear the main responsibility for this development. First, flexible accumulation, with its diverse mechanisms of transfer (creation of a market for corporate control, the role of shareholder value in corporate governance, internal financialization, and permanent competition between regions) allowed a planned economy to develop that served the highest returns and maximal profits. Returns and profits no longer appear to be the result of economic performance, but rather their precondition. They are set as obligatory goals for all decentralized corporate units. As a result, the ways in which corporations are managed and controlled are changing and influence management styles and the utilization of personnel. Management decisions increasingly follow stock market fluctuations, the diktat of the quarterly report, and the egoism emerging from stock-market related pay schemes for top management. In this way, a short-termist, market-driven mode of control, fostering competition within companies and among employees, could emerge.

The above-mentioned conditions are the main origin of the new precariousness. To adjust to volatile markets and their rapid fluctuations, and to guarantee planned profit margins for a longer period of time, wages, working hours, and working conditions have become residuals that should adapt flexibly to market situations. Dominant enterprises pass on the pressure of planned profit margins, not only to managers and employees, but also to suppliers and, through them, the dependent segment of small and medium-sized enterprises. The importance of flexible forms of 
employment within the system of added value rises so that corporations can adapt to business cycles. Employers increasingly emphasize external flexibility offered by fixed term contracts, contract and agency work. Apparently, methods of increasing profits are again becoming attractive that are founded on, as Marx termed it, the production of absolute surplus value: longer working hours, lower wages, worsened working conditions, and not least the revitalization of mechanisms of secondary exploitation. To achieve returns of 25 per cent (Deutsche Bank), corporations try to earn extra profits by making labour conditions more flexible and more precarious. Since these competitive advantages are easily copied and only temporary, the motor of this kind of Landnahme must be kept running and fed with new ways of undercutting the competition through such practices as spin-offs, outsourcing, deregulation, wage dumping, and the brutalization of the labour market. The 'planned' stability of shareholder income and profit thus carries in its wake, the growing insecurity of working conditions. In the final analysis, financial market capitalism and precarization are two sides of the same coin.

State policy did not cushion, but rather exacerbated, the pressures towards re-commodification that stemmed from finance-capitalist Landnahme. In Germany, the Social Democrat/Green Party coalition government played a significant role in alleviating the obstacles to the new mode of flexible accumulation. In at least two areas, it set the course of policies that would most likely have roused more resistance had they been proposed by a conservative government: namely the pioneering deregulation of financial and labour markets. As the sum of seemingly gradual changes (Streeck 2009), a rather dramatic transformation of the production model took place. Under the surface of the formal continuance of collective bargaining, worker participation, and protection against dismissal, a flexible system of production based on extreme labour market polarization emerged. The institution of a full-time job with social benefits is dying out. At the same time, there is a rapid rise in so-called atypical and usually insecure or precarious types of jobs (temporary agency work, fixed and parttime contracts, marginal employment). 


\section{From Marginal to Discriminatory Precariousness}

Finance-capitalist Landnahme is not only limited to those sectors of the economy that are oriented toward global markets. As corporate divisions that do not consistently meet their profit targets are closed down or sold off, financial market capitalism strengthens and accelerates structural transformation. Credit institutions and financial reporting standards confront small and medium-sized enterprises with the logic of financial capitalism (Bluhm and Schmidt 2008). In their competition for new businesses and government grants, regions contest with one another as 'collective enterprises' (Dörre and Röttger 2006). At the same time, sectors and fields that employ mostly women in reproductive labour and in which organized labour practices are relatively weak are expanding. Direct production is more and more dependent on an increasingly growing number of reproductive activities, but human services and domestic work are least valued by society and these jobs have little to no protection. The (partial) privatization of previously public services is also an element of the expansionary logic of financial capitalism. The German postal office, Deutsche Bahn (rail services), and Telekom (telecommunications company) have long been managed like profit-oriented private companies. In core business areas, they compete with private companies that keep prices low by wage dumping and by offering precarious working conditions (Röhm and Voigt 2007).

\subsection{Dimensions of Discriminatory Precariousness}

The state itself has adapted to this form of Landnahme (Crouch 2008). Public administrations privatize services restructure themselves according to the principles of new public management. As a result, marginalized groups such as the long-term unemployed are now being referred to as government's clients. Put under pressure by rules that broadly define which work they can be 'reasonably expected' to accept, they develop an entrepreneurial relationship to their own labour power (Bescherer et al. 2008). The ideological driver of this internally-oriented Landnahme (based on recommodification) is a new spirit of capitalism which defines freedom only in 
negative terms - as the absence of force - and seeks to legitimize the restructuring of financial capitalism, by focusing on individual responsibility and self-determination as liberating acts (Boltanski and Chiapello 2007). However, it is true that the ideological offensive of the finance-capitalist logic of competition does not culminate automatically in marketization. In Germany, in particular, policies that aim to strengthen the coordination of markets are confronted with cumbersome institutional filters, as well as conflicting bounded rationalities. Nevertheless, this ideological transfer has transformed society's mode of regulation. The dismantling of organized labour relations and collective bargaining systems are the best example of this process.

The dismantling of collective protective rights and social welfare systems - for which the erosion of industry-wide collective agreements is only one example - hits those sectors particularly hard, where trade unions are weak. This is evident in the low-wage and non-profit sectors with high levels women workers, and in regions with mostly small and middle-sized enterprises, as well as in the expanding segment of 'immaterial' labour, where works councils are a rare exception. In particular, in the media, arts and the non-profit sector - including institutes of adult education and (interim) employment institutions - the borders between creative and precarious work are fluid. The areas hit the hardest by precariousness are those offering unskilled, low-paid jobs. Usually, these are service jobs in domestic work and caretaking, in hotels and restaurants, or in workintensive courier and helper positions.

In Germany, most employees are formally still in protected positions. These positions define the societal standards for income and job security. But the social environment has radically changed and it is in the throes of a transformation from marginal to discriminatory precariousness. Precarization is less than ever the exclusive problem of the socially marginalized. Instead three structural forms of precariousness are emerging that - paradoxical as it may sound - cover all 'zones of social cohesion' (Castel 2000). At the bottom of the social hierarchy are those groups which Marx already termed the 'surplus population' of capitalist society (Marx 1977: 673). The majority of Germany's 7.4 million welfare recipients are part of this group, including around 2.5 unemployed and 1.3 million 
underemployed people (2007). As long as individuals are able to work, the great majority of this socially and culturally heterogeneous group strives to become integrated in the primary labour market. Only a small minority of people, with no realistic chance of securing their own livelihood, are able to subjectively transform the lack of objective opportunities into a voluntary life, without paid employment (Dörre et al. 2013; Bescherer et al. 2008).

The truly 'precarious' worker can be distinguished from the 'surplus population'. The former refers to the expanding group of people who, for long periods of time, are dependent upon insecure, low-paid jobs, with low social prestige. The $46.2 \%$ increase of atypical employer-employee relations (temp work, limited and part-time contracts, marginal employment; 19982008) is one - albeit highly unreliable - indicator of the trend towards precariousness. Although not all atypical employment is necessarily precarious, as a rule non-standardized job relations are linked to much lower salaries and higher risks of unemployment and poverty (German Federal Statistics Office, August 19, 2009). In 2008, Germany's employment statistics revealed that 7.7 million people held atypical job in contrast to 22.9 million in standard employment. Not included in these numbers were the 2.1 million freelancers or single-person businesses (German Federal Statistics Office, August 19, 2009) as well as the rapidly expanding segment of the regularly employed workforce, whose salary keeps them below the poverty line (11.1 per cent of all people in regular employment in 2006). Currently, around 6.5 million people earn less than two-thirds of the national median income (Bosch and Weinkopf 2007). Altogether, 42.6\% of all low-income workers have a 'normal' job. Of these, $30.5 \%$ are women and $45.6 \%$ have few formal qualifications. However, around three-quarters of all low-income workers have completed vocational training or even hold an academic degree (Kalina, Vanselow and Weinkopf 2008: 20-24). Increasing wage differentiation and decreasing upward mobility in the low-income sector signalizes the persistence of precarious situations (Bosch and Kalina 2007: 42 ff.). 


\subsection{Precariousness and Social Classes}

It is particularly relevant that the real earnings of the lower quarter of wage earners have recently gone down, by $14 \%$ over a ten year period (1997-2007; German Federal Statistics Office, August 19, 2009). While employees in at least partially protected employment are able to maintain their standard of living, or at least minimize reductions, the gap between precarious groups and mainstream society is continually growing. This development illustrates the effectiveness of mechanisms of secondary exploitation. Collective protection mechanisms are traditionally most effective where workers were and are best able to advance their interests - in the public sector and in large corporations, both of which have a high percentage of male full-time employees. The distribution among different sectors has traditionally been determined by the construction of gender, ethnicity, and nationality. Despite improvements in their integration into the educational system and the labour market, women are still overrepresented in the less protected sectors. The gender differences are not only the result of direct forms of politicalinstitutional discrimination, but are also produced by subtle social mechanisms of subordination, i.e. the 'immense symbolic machine tending to ratify [...] masculine domination' (Bourdieu 2001: 9).

What is new is that traditional forms of precariousness as experienced by, for example, women and immigrants, increasingly blends with the experience of precariousness by groups that were formerly protected. The fear of losing one's job also haunts large segments of wage earners, still in standard employment. These fears do not necessarily reflect objective threats, but neither are they only an indication of an exaggerated desire for security. Competition between regions, falling real wages, and the slow hollowing out of collective bargaining agreements are reality for many unionized employees. This produces fear of not being able to make it into or remain in the middle class. There are still indications that the mid-section of society is fairly stable, but in light of increasing precarious jobs 'in particular at the fringe of the social mainstream', sinking income margins, and growing labour market risks, even those at the 'core of the mid-section of society' are concerned about losing their livelihood (Werding and Müller 2007: 157). While fear of losing status leads protected employees to defend their positions, individuals with precarious jobs are trying to get protected 
employment. Precarious wage earners, however, do not command the power, communication or organization structures to successfully fight for a collective improvement of their position. In this, their situation is in some respects similar to that of the French small-holding peasants described by Marx (1963) in the Eighteenth Brumaire of Louis Bonaparte. They represent a particular societal position, without being able to form a class or a class fraction of their own.

We can already speak of a class division between those employees still in protected positions, defending what remains of their social property and a heterogeneous sub proletariat, currently unable to form an independent political class. On the one hand, current forms of precariousness exhibit the characteristics of a class (Burzan 2009), and on the other one, they can be found within varying economic and social classes and class fractions (Castel 2009: 30-31). For this reason, there is neither a homogenous lower class nor a clearly defined precarious class. Instead, a number of different forms of precariousness can be identified (Castel and Dörre 2009). For example, for academics, precarious employment is sometimes linked to creative work. On the other hand, full-time employment, with a social safety net, can be deadening, monotonous, and very stressful (Paugam 2009: 175-196). Precariousness work and employment can also come together without being subjectively experienced as such. Sometimes precariousness is a temporary condition, a passing status on the way to a better social position; sometimes however precarious situations become stable.

What it is sure is that the revival of a visible reserve army mechanism furthers the transition to a new manner of societal integration and domination. Instead of integration based primarily on partaking of material wealth and democratic structures and the integration of labour power, new forms of integration are emerging in which the subtle effect of market-driven disciplining mechanisms and government force play a much greater role. Disciplining by market and government can, at least in a wealthy society, functionalize many hopes, fears, and traditions. It not only causes the 'destabilization of the stable' (Castel 2000: 357), but - by disciplining one and removing elementary prerequisites for resistance in the other - it also furthers a strange stabilization of the instable. The marginalized and the precariousness embody a fate that employees, who are still integrated, will 
try to avoid by using all means at their disposal. Not only abstract market relations, but also the victims of market management have a disciplining effect. They are an object-lesson, in what it can happen to individuals and groups, when they are caught in collective processes of decline.

\section{Precariousness and the Critique of Capitalism}

To sum up, for the systematic stabilization of finance-driven Landnahme that generates demands (targets for returns and profits) that the real economy is unable to fulfil, a modus operandi is necessary that continually feeds new, unexploited assets, into the cycle of capital. This includes the utilization of the reserve army mechanism. Its purpose is not only to allow corporations, as David Harvey (2005b: 141) argues, to throw 'workers out of the system at one point in time, in order to have them to hand for purposes of accumulation at a later point in time'. Rather a precarious sector is created at the margins where the 'surplus population' resides and has no chance of ever being integrated into regular employment. Between relatively protected employment and decoupled groups, a very heterogeneous 'precariousness' (Standing 2011) has emerged that moves between insecure, usually low-paid jobs, training programs, and unemployment. Precarious forms of working and living are a continuous balancing act. It is constantly necessary to mobilize all one's energy in order to advance into a better position; behind repose looms the danger of being permanently excluded from regular salaried employment. The expansion of the 'zone of vulnerability' means that experiences of this zone are permanently established in the employment system. While this experience is universal, its processing by individuals or social groups differs according to age, gender, nationality, qualification, and biographical background.

In essence, precariousness groups fulfil a function similar to that of the traditional sector before 1945. Even if tendencies toward precarization do not have a direct impact on organized internal labour markets, they do result in a reduction of normative expectations, regarding work and life, and limit wage demands. Whenever permanent employees are confronted with flexible and often highly-motivated co-workers, who do the same work under much worse conditions, they begin to see their position as a privilege 
to be defended tooth and nail (Holst, Nachtwey and Dörre 2009). Empirical research suggests that at the end of the 1980s, younger employees in particular put more value on the content and socio-communicative aspects of their work (Baethge, Hantsche and Pelull 1989). Today however, empirical studies clearly show that job security and an acceptable income are the unquestioned preference of a large percentage of employees, and qualitative expectations take a back seat (Schröder and Urban 2009). Fear for one's own security and the individual's social status, stoked repeatedly by processes of precariousness, furthers - just at Boltanski and Chiapello (2007) predicted - corporate control over workers. Germany's new labour market regime that emerged with the reform of the social welfare system promotes this tendency even more. Although the underlying conditions are completely different, the labour market regime fulfils a similar function to compulsory laws, during the post-feudal era (Marx) and the workhouses (Foucault) of the early capitalist era. The system amplifies the value of precarious jobs and increases the necessity of working, creating a disciplining pressure meant to mobilize (potential) employees, for labour within a flexible and at the same time strongly polarized world of work.

Jürgen Habermas (1987: 356ff.) linked his diagnoses of current society to the 'colonization of the life-world' and to the pacification of the class conflict through the welfare state; finance-capitalist Landnahme has long fed on this specific regulatory ability. This is not to suggest that industrial class conflict is returning in its familiar historical form. Evidence suggests that from the beginning, finance-capitalist Landnahme was 'a project to achieve the restoration of class power' (Harvey 2005a: 16). But despite the undeniable political success of this project, in creating inequality and finance oligarchy (Marx 1976 [1894]: 454), the 'active renters' (Chesnais 2004: 224) are not able to generate heterodox class power on the side of the dominated.

On the contrary, 'it is increasingly difficult for any other, than increasingly confident shareholding and "executive" classes to perceive themselves [...] as clearly defined social groups' (Crouch 2004: 53). The discriminating form of precariousness plays a major role in this 'postdemocratic $^{\prime}$ - as Colin Crouch calls it - trend. Precariousness promotes struggles over status and relative deprivation among permanent employees, precarious workers, and excluded subjects. Precarious working and living 
conditions slowly deprive those, who are constantly overwhelmed by worries about getting through the next days, of the energy necessary for engaging in civil society, political, or union activities. Or it provokes - as in the French banlieus and more recently among Greek youth - 'bargaining by riots' with extremely ambivalent results, for the constitution of democracy in Western societies.

However, at the same time, a systematic disfunction of precarization can be observed. In fact, the process of precariousness undermines the ability to plan the future, because the social conditions that make possible a rational behaviour in market relationships are rarely present. Already we can see that constant insecurity negatively affects the loyalty of permanent staff to their employer. Quality defects and sophisticated electronic monitoring systems attest to this phenomenon. Demographic change and a lack of skilled workers affect some segments of the labour market and put further limits to precariousness. The discovery of the precariousness for union interests, as expressed in campaigns for a minimum wage and against temporary agency work, should also show some positive effects. Thus seen, the financial crisis may perhaps create opportunities for 'politics of deprecariousness' (Brinkmann et al. 2006). Whether and how they are used it is impossible to predict at this point. A first step would be influencing the discourse through revitalized, up-to-date social critique. The measure of such a critique can no longer be the Fordist labour society and its model of male dominated -'normal' employment. A new social critique must make it clear that income and, principally, job security are a condition, and not a prerequisite, for individual flexibility in and outside of the working world, for both men and women (Paugam 2009: 175-196). The main elements for the politics of de-precariousness - including linking the social safety net to shorter working hours and flexible interlinking of phases of work, education and training, and family orientation - have been sufficiently laid out (for example Dörre 2009: 260f.). However, if finance-capitalist Landnahme is sustained in the future, there is no chance of realizing such a program. This brings us to a decisive problem, an alternative to today's financial market capitalism. Standing up for a fundamental social alternative, and thus political antagonism, social movements of earlier eras are strong. If the discourse focusing on a humane transformation of capitalism is not 
revitalized and the power elites are not confronted with true antagonism, the anti-human, anti-democratic tendencies inherent to processes of precarization are likely to become even stronger. It is up to social actors to draw their own conclusions.

\section{Acknowledgement:}

This article was translated by Laura Radosh, Jennifer Olson, Hajo Holst.

\section{References:}

Arendt, Hannah. 2006. Elemente und Ursprünge totalitärer Herrschaft. Antisemitismus, Imperialismus, totale Herrschaft. München: Piper. The Origins of Totalitarianism. Florida: Harcourt.

Aulenbacher, Brigitte. 2009. Die soziale Frage neu gestellt. Gesellschaftsanalysen der Prekarisierungs- und Geschlechterforschung. In Prekarität, Abstieg, Ausgrenzung. Die soziale Frage am Beginn des 21. Jahrhunderts, eds. Robert Castel and Klaus Dörre, 65-80. Frankfurt am Main/New York: Campus.

Baethge, Martin, Brigitte Hantsche and Wolfgang Pelull. 1989. Jugend: Arbeit und Identität. Lebensperspektiven und Interessenorientierung von Jugendlichen. Opladen: Leske Budrich.

Bescherer, Peter, Klaus Dörre, Silke Röbenack and Karen Schierhorn. 2008. Eigensinnige "Kunden". Auswirkungen strenger Zumutbarkeit auf Langzeitarbeitslose und prekär Beschäftigte. In Eigensinnige "Kunden". Der Einfluss strenger Zumutbarkeit auf die Erwerbsorientierung Arbeitsloser und prekär Beschäftigter, eds. Klaus Dörre, Michael Behr, Peter Bescherer, Silke Röbenack, Tina Seiwert, Katrin Kuhirt and Karen Schierhorn, 10-36. SFB 580 Mitteilungen 26.

Bluhm, Katharina and Rudi Schmidt. 2008. Change in SMEs. Towards a new European capitalism? Basingstoke: Palgrave Macmillan.

Boltanski, Luc and Ėve Chiapello, 2007. The New Spirit of Capitalism. New York/London: Verso.

Boltanski, Luc and Ève Chiapello. 2003. Der neue Geist des Kapitalismus. Konstanz: UVK.

Bosch, Gerhard and Thorsten Kalina. 2007. Niedriglöhne in Deutschland. Zahlen, Fakten, Ursachen. In Arbeiten für wenig Geld. Niedriglohnbeschäftigung in Deutschland, eds. Gerhard Bosch and Claudia Weinkopf, 20-105. Frankfurt am Main/New York: Campus.

Bosch, Gerhard and Claudia Weinkopf. 2007. Arbeiten für wenig Geld. Niedriglohnbeschäftigung in Deutschland. Frankfurt am Main/New York: Campus. 
Bourdieu, Pierre. 2005. Die männliche Herrschaft. Frankfurt am Main: Suhrkamp.

Bourdieu, Pierre. 2001. Masculine Domination. Stanford: Stanford University Press.

Bourdieu, Pierre. 2000. Zwei Gesichter der Arbeit. Interdependenzen von Zeitund Wirtschaftsstrukturen am Beispiel einer Ethnologie der algerischen Übergangsgesellschaft. Konstanz: UVK.

Brinkmann, Ulrich, Klaus Dörre, Silke Röbenack, together with Klaus Kraemer und Frederic Speidel. 2006. Prekäre Arbeit. Ursachen, Ausmaß, soziale Folgen und subjektive Verarbeitungsformen unsicherer Beschäftigungsverhältnisse. Bonn: Friedrich-Ebert-Stiftung.

Burzan, Nicole. 2009. Prekarität und verunsicherte Gesellschaftsmitte. Konsequenzen für die Ungleichheitstheorie. In Prekarität, Abstieg, Ausgrenzung. Die soziale Frage am Beginn des 21. Jahrhunderts, eds. Robert Castel and Klaus Dörre, 307-318. Frankfurt am Main/New York: Campus.

Castel, Robert. 2009. Die Wiederkehr der sozialen Unsicherheit. In Prekarität, Abstieg, Ausgrenzung. Die soziale Frage am Beginn des 21. Jahrhunderts, eds. Robert Castel and Klaus Dörre, 21-34. Frankfurt am Main/New York: Campus.

Castel, Robert. 2005. Die Stärkung des Sozialen. Leben im neuen Wohlfahrtsstaat. Hamburg: Hamburger Edition.

Castel, Robert. 2000. Die Metamorphosen der sozialen Frage. Eine Chronik der Lohnarbeit. Konstanz: UVK.

Castel, Robert and Klaus Dörre (eds.). 2009. Prekarität, Abstieg, Ausgrenzung. Die soziale Frage am Beginn des 21. Jahrhunderts. Frankfurt am Main/New York: Campus.

Chesnais, Francois. 2004. Das finanzdominierte Akkumulationsregime. Theoretische Begründung und Reichweite. In Die globale Enteignungsökonomie, ed. Christian Zeller, 217-254, Münster: Westfälisches Dampfboot.

Crouch, Colin. 2008. Postdemokratie. Frankfurt am Main: Suhrkamp.

Crouch, Colin. 2004. Post-Democracy. Cambridge: Polity Press.

Dahrendorf, Ralf. 1967. Society and Democracy in Germany. New York: Doubleday.

Dörre, Klaus. 2009. Prekarität im Finanzmarkt-Kapitalismus. In Prekarität, Abstieg, Ausgrenzung. Die soziale Frage am Beginn des 21. Jahrhunderts, eds. Robert Castel and Klaus Dörre, 35-64. Frankfurt am Main/New York: Campus.

Dörre, Klaus, Karin Scherschel, Melanie Booth, Tine Haubner, Kai Marquardsen and Karen Schierhorn. 2013. Bewährungsproben für die Unterschicht? Frankfurt am Main/New York: Campus. 
Dörre, Klaus, Stephan Lessenich and Hartmut Rosa. 2009. Soziologie Kapitalismus - Kritik. Eine Debatte. Frankfurt am Main: Suhrkamp.

Dörre, Klaus and Bernd Röttger. 2006. Im Schatten der Globalisierung. Wiesbaden: VS.

German Federal Statistics Office. 2009. Niedrigeinkommen und Erwerbstätigkeit. Begleitmaterial zum Pressegespräch. August 19. Frankfurt am Main/Wiesbaden: Statistisches Bundesamt.

Gramsci, Antonio. 1991-2002. Gefängnishefte. Kritische Gesamtausgabe. Band ein bis zehn. Hamburg: Argument.

Gramsci, Antonio. 1991. Gefängnishefte 1. 1, Heft. Kritische Gesamtausgabe, 1194. Hamburg: Argument.

Gramsci, Antonio. 1999. Gefängnishefte 9. 22. Bis 29. Heft. Kritische Gesamtausgabe, 2062-2249. Hamburg: Argument.

Habermas, Jürgen. 1987. Theorie des kommunikativen Handelns. Frankfurt am Main: Suhrkamp.

Harvey, David. 2005a. A Brief History of Neoliberalism. Oxford: Oxford University Press.

Harvey, David. 2005b. Der neue Imperialismus. Hamburg: VSA.

Holst, Hajo, Oliver Nachtwey and Klaus Dörre. 2009. Funktionswandel von Leiharbeit. Neue Nutzungsstrategien und ihre arbeits- und mitbestimmungspolitischen Folgen. OBS-Arbeitsheft 61. Frankfurt am Main: Otto-Brenner-Stiftung.

Kalina, Thorsten, Achim Vanselow and Claudia Weinkopf. 2008. Niedriglöhne in Deutschland. SPW - Zeitschrift für sozialistische Politik und Wirtschaft 31 (164): 20-24.

Lutz, Burkart. 1984. Der kurze Traum immerwährender Prosperität. Eine Neuinterpretation der industriell-kapitalistischen Entwicklung im Europa des 20. Jahrhunderts. Frankfurt am Main/New York: Campus.

Luxemburg, Rosa. 2003. The Accumulation of Capital. New York/London: Routledge Classics.

Marx, Karl. 2007 [1867]. Capital: A Critique of Political Economy. Volume I: The Process of Capitalist Production. New York: Cosimo Classics

Marx, Karl. 1976 [1894]. Das Kapital. Band 3. Der Gesamtprozeß der kapitalistischen Produktion. Berlin: Dietz.

Marx, Karl. 1977 [1867]. Das Kapital. Band 1. Der Produktionsprozeß des Kapitals. MEW 23. Berlin: Dietz.

Marx, Karl. 1963. The Eighteenth Brumaire. New York: International Publishers.

Mooser, Josef. 1984. Arbeiterleben in Deutschland 1900-1970. Klassenlagen, Kultur und Politik. Frankfurt am Main: Suhrkamp.

Paugam, Serge. 2009. Die Herausforderung der organischen Solidarität durch die Prekarisierung von Arbeit und Beschäftigung. In Prekarität, Abstieg, Ausgrenzung. Die soziale Frage am Beginn des 21. Jahrhunderts, 
eds. Robert Castel and Klaus Dörre, 175-196. Frankfurt am Main/New York: Campus.

Röhm, Uli and Wilfried Voigt. 2007. Das Lohndumping-Kartell. Großverlage bekämpfen den Post-Mindestlohn. Hamburg: VSA.

Schröder, Lothar and Hans-Jürgen Urban. 2009. Gute Arbeit. Handlungsfelder für Betriebe, Politik und Gewerkschaften. Frankfurt am Main: BundVerlag.

Standing, Guy. 2011. The Precariat. The New Dangerous Class. London: Bloomsbury.

Streeck, Wolfgang. 2009. Re-Forming Capitalism. Institutional Change in the German Political Economy. Oxford: Oxford University Press.

Thompson, Edward P. 1966. The Making of the English Working Class. New York: Vintage.

Werding, Martin and Marianne Müller. 2007. Globalisierung und gesellschaftliche Mitte. Beobachtungen aus ökonomischer Sicht. In Zwischen Erosion und Erneuerung. Die gesellschaftliche Mitte in Deutschland. Ein Lagebericht, Herbert-Quandt-Stiftung, 103-161. Frankfurt am Main: Societäts-Verlag. 